\title{
Sosial ulikhet i ungdoms helse: Er helseatferd viktig?
}

\author{
Torbjørn Torsheim, Ingrid Leversen og Oddrun Samdal \\ Institutt for utdanning og helse, Universitet i Bergen \\ Korrespondanse: Torbjørn Torsheim, Institutt for utdanning og helse, HEMIL-senteret, Christies gt. 13, Pb 8707, N-5020 Bergen \\ Telefon: $55583301 \quad$ E-post: torbjoern.torsheim@psyhp.uib.no
}

\begin{abstract}
SAMMENDRAG
Studier har påvist sosioøkonomiske forskjeller i ungdoms helse. I følge atferdsforklaringer på ulikhet har ungdom fra familier med lav sosioøkonomisk status dårligere helse som et resultat av at de har et høyere nivå av risikoatferd og et lavere nivå av beskyttende atferd. Det empiriske grunnlaget for en slik forklaring er imidlertid svakt. Målet med studien var å undersøke rollen helseatferd kan ha for sosioøkonomiske forskjeller i ungdoms helse. Studien bygger på data fra den norske delen av "Helsevaner blant skoleelever 2005/06”. Et utvalg av 6447 skoleelever i aldersgruppen 11 til 16 år besvarte spørreskjemaer. Sosioøkonomisk status ble målt med en indeks for foreldrenes status bestående av foreldrenes yrke, familiens velstand og antall bøker i hjemmet. Helseatferd ble målt ved epidemiologiske indikatorer for kosthold, fysisk aktivitet, stillesittende aktivitet/ser mye på tv, røyking og alkoholbruk. Ordinal logistisk regresjonsanalyse viste at ungdom med lav status hadde høyere odds ratioer for selvrapportert dårligere helse. Kontroll for helseatferd resulterte i en klar reduksjon i odds ratioen for dårligere helse, en indikasjon på delvis mediering. Stianalyse indikerte at røyking, fysisk aktivitet og inntak av frukt og grønnsaker bidro til mediering av sammenhengen mellom sosioøkonomisk status og selvrapportert helse. Samlet tyder resultatene på at helseatferd kan være en medierende mekanisme for sosioøkonomiske forskjeller i ungdoms helse. Langtidskonsekvensen av helseatferd antyder et behov for intervensjoner som retter seg mot flere former for helseatferd.
\end{abstract}

\section{Torsheim T, Leversen I, Samdal O. Adolescent health inequality: are behavioural factors important? Nor J Epidemiol 2007; 17 (1): 79-86.}

\section{ENGLISH SUMMARY}

A number of studies have reported socioeconomic differences in adolescent health. According to behavioural models of health inequalities, adolescents from low SES families might have poorer health owing to a higher level of risk behaviours and a lower level of protective behaviours, but the empirical evidence in support of such behavioural mediation is scant. The objective of this paper is to examine the role of behavioural mediating factors in adolescent health inequalities. The paper is based on the Norwegian part of the "Health behaviour in school-aged children 2005/06 (WHO)". A sample of 6447 students aged 11, 13, 15 and 16 completed self-report questionnaires. Socioeconomic status was measured by a parental SES index combining adolescents' reports on parental occupation, family affluence and number of books at home. Behavioural risk factors were measured with epidemiological indicators on dieting, physical activity, sedentary behaviour, and smoking. Logistic regression analysis revealed that adolescents with lowest SES had higher odds for self-rated fair or poor health, compared to those with highest SES. Controlling for behavioural factors resulted in a clear reduction of the odds ratios for self-rated health, indicating partial behavioural mediation. Path models with specification of indirect effects indicated that behaviours with strong evidence of mediation were smoking, physical activity and fruit and vegetable consumption. Results indicate that behavioural factors might be important mediating mechanism for socioeconomic differences in adolescent self-rated health. The longer-term consequences of such behavioural factors suggest a need for interventions targeting multiple adolescent health behaviours, rather than isolated efforts on single behaviours.

Sosial ulikhet i sykelighet og dødelighet kan forstås som et resultat av langvarige prosesser som starter flere tiår før ulikheten er mulig å observere (1). Skal en forklare sosioøkonomiske forskjeller i dødelighet og sykdom kan det være nødvendig å kartlegge hvordan sosioøkonomiske forhold påvirker helse over hele livsløpet, også i perioder hvor helsen er tilsynelatende god. Ungdomsperioden har vært betraktet som en periode med sosial utjevning, hvor sosioøkonomiske for- skjeller er lite framtredende eller helt fraværende (2). Nyere studier har imidlertid påvist en sammenheng mellom familiens sosioøkonomiske status og helse, både i løpet av ungdomstiden (3-6) og senere i livet som voksen (1). Snarere enn å være en periode for utjevning, tyder disse studiene på at ungdomstiden er en periode for utvikling og vedlikehold av ulikhet, men mekanismene for denne sammenhengen er fremdeles uavklart. 
Ungdom har ikke en selvstendig sosioøkonomisk status, og dermed blir studiet av sosial ulikhet blant ungdom et spørsmål om i hvilken grad foreldre og hjemmeforhold påvirker prosesser med betydning for helse. Både familiens materielle forhold, de psykososiale forholdene $\mathrm{i}$ familien og foreldrenes atferd kan bidra til at ulikhet i helse oppstår og vedlikeholdes. Delvis kan ulikhet $i$ helse oppstå fordi materielle forskjeller har direkte konsekvenser for familiens levekår. Ulikhet kan også være et resultat av at barn i familier med lav sosioøkonomisk status (SØS) opplever en lavere grad av sosial støtte (7) og er utsatt for et høyere nivå av familiekonflikter (8). En tredje mulig forklaring er at familiens sosioøkonomiske status påvirker ungdoms helseatferd. Mange av atferdsmønstrene med størst betydning for helse, inkludert røyking, fysisk aktivitet og kosthold, etableres i løpet av ungdomsårene. Familiens sosioøkonomiske status påvirker utviklingen av ungdoms helseatferd gjennom foreldrenes rolle som modeller og som forsterkere av atferd. Studier har påvist sosioøkonomiske forskjeller i ungdoms kostholdsvaner (9), fysisk aktivitet og tobakksrøyking (10), men i mindre grad for alkoholvaner (11). Sosioøkonomiske forskjeller $\mathrm{i}$ fordelingen av helseatferd hos unge kan derfor være én av årsakene til sosial ulikhet $\mathrm{i}$ helse både $\mathrm{i}$ ungdomstiden og senere i livet.

I et livsløpsperspektiv kan sosioøkonomiske forskjeller i atferd være av særlig stor betydning, fordi sykdommer med stor grad av sosial ulikhet, for eksempel hjerte-karsykdommer, delvis er atferdsmediert. I den grad ulikhet $\mathrm{i}$ atferd vedlikeholdes, vil en over tid også kunne forvente ulikhet i sykelighet. En begrensing ved tidligere forskning er at studiene ikke har belyst hvordan ulike former for helseatferd samvirker $\mathrm{i}$ forhold til sosial ulikhet $\mathrm{i}$ helse, eller den relative betydningen ulike former for helseatferd har for sosial ulikhet i helse. Enkeltfaktorer kan isolert sett ha liten betydning for sykdomsrisiko, men kan i samspill med flere faktorer ha stor betydning. Tidligere forskning gir heller ikke svar på om ulikhet i helseatferd opptrer sekundært $\mathrm{i}$ forhold til sosial ulikhet i psykososiale forhold. I følge den psykososiale hypotesen er barn fra lavere SØS utsatt for høyere eksponering for stressende livshendelser og lavere nivå av sosial støtte. Enkelte former for helseatferd, som tobakksrøyking og alkoholbruk, kan betraktes som tilpasning til vanskelige eller ufordelaktige psykososiale forhold $(12,13)$. For å kunne avgrense sosioøkonomiske forskjeller i helseatferd kan det også være nødvendig å ta hensyn til forskjeller i psykososiale forhold.

Formålet med artikkelen er å undersøke i hvilken grad det er sosioøkonomiske forskjeller i helserelatert atferd blant skoleungdommer i Norge, og i hvilken grad slike forskjeller $\mathrm{i}$ atferd kan forklare forskjeller $\mathrm{i}$ ungdommens selvrapportert helse. Artikkelen baserer seg på data fra den landsdekkende studien "Helsevaner blant skolelever. En WHO studie i flere land 2005/06", som ble gjennomført i desember 2005.

\section{Metode}

For å få representative utvalg av norske 11-, 13-, 15og 16-åringer ble utvalget basert på en liste over 6., 8., og 10. klasser i den norske grunnskolen, og en liste over alle grunnkursklasser i landet. Populasjonen bestod av 61640 6.klassinger, 62696 8.klassinger, 62266 10.klassinger og 65841 elever med studierett til grunnkurs i den videregående skolen. For å oppnå et endelig utvalg med 1700 elever pr. aldersgruppe, ble det estimert et behov for å trekke ut 149 6.klasser, 116 8.klasser, 115 10.klasser og 171 grunnkursklasser. Av totalt 551 utvalgte klasser deltok 378. Av de til sammen 7764 elevene på deltagende skoler deltok 6624 i undersøkelsen. De viktigste årsakene til ikke-deltagelse var sykdom på dagen for undersøkelsen (528 elever), annet uspesifisert fravær (224 elever) og at foreldre ikke ønsket at eleven skulle delta (190 elever). For 98 elever var årsaken til frafall ukjent. Kvalitetssikring av data ble foretatt av Norsk Samfunnsvitenskapelig Datatjeneste (NSD), etter en standardisert rutine, hvor spørreskjema med inkonsistente og/eller manglende svar på nøkkelvariabler ble fjernet. Dette førte til at 177 elever ble tatt ut av materialet. Etter kvalitetssikring bestod det endelige utvalget av 1586 elever på 6.trinn (gjennomsnittsalder 11,5, SD=0,29), 1591 elever på 8.trinn (snittalder 13,5, SD=0,29), 1534 elever på 10.trinn $(15,5, \mathrm{SD}=0,29)$ og 1736 elever på Grunnkurs $1(16,5, \mathrm{SD}=0,34)$. Studien er godkjent av Regional komité for medisinsk forskningsetikk.

Det er vanlig å måle sosioøkonomisk status (SØS) ved hjelp av yrke, utdanning og inntekt. I studier av barn og unge kan det være nødvendig å supplere med andre indikatorer, både fordi barn og unge ofte mangler kunnskap om foreldres inntekt og utdanning, og fordi SØS kan fremtre på andre måter i barnefamilier enn i eldre deler av populasjonen. I studien vår ble SØS målt ved indikatorer for mors og fars yrke, antall bøker i hjemmet og en indeks for materielle levekår. Kodingen av mors og fars yrke var basert på et todelt spørsmål med åpne svaralternativer: Har din far (mor) jobb? Svaralternativene var: "Ja"; "Nei"; "Vet ikke"; "Har ikke eller treffer ikke far min". Dette ble fulgt opp med et åpent spørsmål: ”Om du svarte JA, kan du da skrive hvor han arbeider (for eksempel sykehus, restaurant, skole). "Skriv ned nøyaktig hva han gjør der". Trenede kodere klassifiserte svarene på disse spørsmålene til én av følgende fem kategorier, i følge en standardisert klassifisering (14): Klasse I profesjonelle yrker; Klasse II ledende yrker; Klasse IIIN funksjonær ikke-manuell; Klasse IIIM faglært manuell; og som femte kategori Klasse IV samt Klasse V halvfaglært manuell og ufaglært. Antall bøker ble målt med spørsmålet: Hvor mange bøker har familien din hjemme? Svaralternativene var "Ingen"; "1-10 bøker"; "11-50 bøker"; "51-100 bøker"; "101-250 bøker"; "251-500 bøker" og "Mer enn 500 bøker".

Den materielle levekårsindeksen (15) bestod av en samlet sumskåre basert på antall biler i familien (0-2), 
eget soverom (0-1), antall PC'er i hjemmet (0-3) og antall ferier siste året (0-3).

Kostholdsvaner ble målt ved spørsmålet: Hvor mange ganger i uken spiser eller drikker du noe av dette (frukt/grønnsaker/godteri (f.eks. drops og sjokolade)/Cola, brus eller andre leskedrikker med sukker)?". Svaralternativene var "Aldri"; "Sjeldnere enn en gang per uke"; "2-4 dager i uken"; "5-6 dager i uken"; "En gang hver dag"; og "Flere ganger hver dag”. Fysisk aktivitet ble målt med spørsmålet: I løpet av de siste 7 dagene: Hvor mange av disse dagene var du fysisk aktiv i minst 60 minutter? Svaralternativene gikk fra "Ingen dager" (0) til "7 dager" (7).

TV-titting ble målt ved hjelp av spørsmålet: Hvor mange timer for dagen pleier du å se på tv på fritiden din (regn også med video)? Sett ett kryss for ukedager og ett kryss for helgen. Svaralternativene var "Ikke i det hele tatt"; "ca 1/2 time"; "ca 1 time"; "ca 2 timer"; "ca 3 timer for dagen"; "ca 4 timer for dagen"; "ca 5 timer for dagen"; "ca 6 timer for dagen"; og "ca 7 timer eller mer for dagen". Tobakksrøyking ble målt ved hjelp av spørsmålet: "Hvor ofte røyker du?" Svarkategoriene var: "Hver dag"; "Hver uke"; "Sjeldnere enn en gang i uken"; og "Ikke i det hele tatt". Alkoholbruk ble målt ved spørsmålet: Har du noen gang drukket så mye alkohol at du har vært skikkelig beruset (full)? Svaralternativer var "Nei, aldri"; "Ja, en gang"; "Ja, 2-3 ganger"; "Ja, 4-10 ganger"; og "Ja, mer enn ti ganger".

Psykososiale forhold ble målt ved hjelp av en indeks basert på en kombinasjon av mobbing, opplevde vektproblemer, opplevd skolerelatert stress, og vanskelige relasjoner til venner og foreldre. Ettersom problemstillingen for studien inkluderer psykososiale variabler som mulige tredjevariabler, ble det konstruert en summert indeks med skårer fra 0 (ingen problemer) til 1 (alle problemer er til stede).

Utvalgets selvrapporterte helse ble målt med spørsmålet: Vil du si at helsen din er ......"Svært god"; "God"; "Bra"; eller "Dårlig"?

\section{ANALYSER}

Alle statistiske analyser ble stratifisert etter kjønn. Analysene ble gjennomført med programpakkene SPSS14.0, STATA 9.2 SE, og Mplus 4.1. For å få en samlet indeks for sosioøkonomisk status ble det gjort en kategorisk prinsipalkomponentanalyse (16) med programpakken SPSS, hvor de tre indikatorene for SØS ble inkludert. Analysen viste en klar førstekomponent der alle tre indikatorer ladet høyt. Den estimerte komponenten ble ridit-transformert slik at en skåre på 1 indikerte en ungdom på toppen av de sosiale hierarkiet, mens en skåre på 0 representerer en ungdom lavest $\mathrm{i}$ hierarkiet. Elever med ridit-skårer blant de laveste $20 \%$ ble klassifisert som "lav SØS", elever i andre, tredje og fjerde kvintil ble klassifisert som "middels SØS", mens elever med ridit-skårer blant de øverste $20 \%$ ble klassifisert som "høy SØS”.
Som et første steg $\mathrm{i}$ analysen ble bivariate sammenhenger mellom SØS og helseatferd analysert i STATA ved hjelp av krysstabeller med korreksjon for designeffekter relatert til klyngeutvalg. I en serie med logistiske regresjonsanalyser ble det estimert odds ratioer for sammenligningen mellom sosioøkonomiske grupper, kontrollert for mulige konfunderende variabler. Dersom forskjeller i helseatferd er sekundære til psykososiale forskjeller, alder og familiestruktur, skulle en forvente betydelig reduksjon i de estimerte forskjellene $\mathrm{i}$ helseatferd etter kontroll for slike mulige konfunderende variabler.

For å vurdere om helseatferd kunne forklare sosioøkonomiske forskjeller i selvrapportert helse ble det foretatt en hierarkisk blokkvis ordinal logistisk regresjonsanalyse med selvrapportert helse som avhengig variabel. Den første blokken inkluderte sosioøkonomisk status, alder og familiestruktur. Den andre blokken inkluderte indeksen for psykososiale forhold. I den tredje blokken ble helseatferd inkludert. På grunn av høy korrelasjon mellom daglig forbruk av frukt og daglig forbruk av grønnsaker ble de to uavhengige variablene frukt og grønnsaker daglig slått sammen til en variabel. Av samme grunn ble også daglig brusdrikking og daglig bruk av godteri kombinert.

Dekomponering av indirekte sammenhenger mellom SØS via helseatferd til selvrapportert helse ble gjennomført i Mplus ved hjelp av Robust vektet minstekvadraters metode. Analysen gjør det mulig å vurdere hvilke av de mellomliggende variablene som bidrar mest til å forklare ulikheten i selvrapportert helse, med en lineær effektstørrelse målt i standardenheter. I de multivariate analysene ble sosioøkonomisk status spesifisert som en prediktor for selvrapportert helse med atferd og psykososiale faktorer som mellomliggende variabler.

De multivariate analysene inkluderte variabler med manglende svar, noe som kan føre til at en stor andel personer faller ut av analysen om de mangler svar på en eller flere uavhengige variabler. I tråd med anbefalinger i litteraturen (17) ble det i stedet for listevis sletting av data valgt å estimere manglende svar basert på den tilgjengelige informasjon i data, ved hjelp av "maximum likelihood" estimering. Slik estimering forutsetter kun tilfeldig manglende svar, gitt de foreliggende kovariatene. Dette er i de fleste tilfeller en mer realistisk forutsetning enn å forutsette fullstendig tilfeldig frafall og gir en mer effektiv bruk av data.

\section{RESUltater}

Tabell 1 viser utvalgets fordeling på nøkkelvariablene i studien. Tabell 2 viser sammenhengen mellom foreldrenes SØS og ulike former for helseatferd. Lavere SØS var forbundet med høyere sannsynlighet for helserelatert risikoatferd både for gutter og jenter. For alle former for helseatferd med unntak for å drikke seg full var det en gradert sammenheng mellom helseatferd og SØS. Barn og unge fra familier med høy SØS hadde 
Tabell 1. Frekvensfordeling på nøkkelvariabler i studien.

\begin{tabular}{|c|c|c|c|}
\hline & Frekvens & Prosent & $\begin{array}{l}\text { Gyldig } \\
\text { prosent }\end{array}$ \\
\hline \multicolumn{4}{|l|}{ Kjønn } \\
\hline Gutt & 3318 & 51,5 & 51,5 \\
\hline Jente & 3129 & 48,5 & 48,5 \\
\hline \multicolumn{4}{|l|}{ Aldersgruppe } \\
\hline 6. klassetrinn & 1586 & 24,6 & 24,6 \\
\hline 8. klassetrinn & 1591 & 24,7 & 24,7 \\
\hline 10. klassetrinn & 1534 & 23,8 & 23,8 \\
\hline Grunnkurs & 1736 & 26,9 & 26,9 \\
\hline \multicolumn{4}{|l|}{ Frukt } \\
\hline Sjeldnere enn daglig & 3938 & 61,1 & 61,5 \\
\hline Daglig & 2466 & 38,3 & 38,5 \\
\hline Manglende svar & 43 & 0,7 & \\
\hline \multicolumn{4}{|l|}{ Grønnsaker } \\
\hline Sjeldnere enn daglig & 4590 & 71,2 & 71,8 \\
\hline Daglig & 1806 & 28,0 & 28,2 \\
\hline Manglende svar & 51 & 0,8 & \\
\hline \multicolumn{4}{|l|}{ Sukkersaker } \\
\hline Sjeldnere enn daglig & 5740 & 89,0 & 89,8 \\
\hline Daglig & 654 & 10,1 & 10,2 \\
\hline Manglende svar & 53 & 0,8 & \\
\hline \multicolumn{4}{|l|}{ Sukkerholdig brus } \\
\hline Sjeldnere enn daglig & 5498 & 85,3 & 85,9 \\
\hline Daglig & 900 & 14,0 & 14,1 \\
\hline Manglede svar & 49 & 0,8 & \\
\hline \multicolumn{4}{|l|}{ Fysisk aktivitet } \\
\hline Sjeldnere enn daglig & 5186 & 80,4 & 86,5 \\
\hline Daglig minst en time aktiv & 808 & 12,5 & 13,5 \\
\hline Manglende svar & 453 & 7,0 & \\
\hline \multicolumn{4}{|l|}{ Tobakksrøyking } \\
\hline Sjeldnere enn daglig & 6029 & 93,5 & 94,3 \\
\hline Daglig & 362 & 5,6 & 5,7 \\
\hline Manglende svar & 56 & 0,9 & \\
\hline \multicolumn{4}{|l|}{ Ser på fjernsyn } \\
\hline Sjeldnere enn fire timer daglig & 4968 & 77,1 & 82,4 \\
\hline Fire timer eller mer daglig & 1064 & 16,5 & 17,6 \\
\hline Manglende svar & 415 & 6,4 & \\
\hline \multicolumn{4}{|l|}{ Har vært full } \\
\hline Sjeldnere enn fire ganger & 5452 & 84,6 & 85,7 \\
\hline Mer enn fire ganger & 909 & 14,1 & 14,3 \\
\hline Manglende svar & 86 & 1,3 & \\
\hline \multicolumn{4}{|l|}{ Selvrapportert helse } \\
\hline God eller svært god helse & 5228 & 81,1 & 82,1 \\
\hline Ikke god helse & 1137 & 17,6 & 17,9 \\
\hline Manglende svar & 82 & 1,3 & \\
\hline
\end{tabular}

lavere nivå av daglig tobakksrøyking, daglig brusdrikking, søtsaker og fjernsyn fire timer eller mer om dagen, og en høyere sannsynlighet for å spise grønnsaker og frukt daglig og for daglig fysisk aktivitet.

Tabell 3 viser at det var betydelige forskjeller i helseatferd selv etter kontroll for alder, familiestruktur og psykososiale forhold. For både gutter og jenter var forskjellen mellom høyeste og laveste SØS sterkest for daglig tobakksrøyking og for daglig drikking av sukkerholdig brus. Forskjellene viste samlet sett en ten- dens til at jenter hadde en høyere odds ratio i sammenligningen mellom høyeste og laveste sosioøkonomiske gruppe. Odds ratioene for jenter var markert høyere for daglig tobakksrøyking, daglig brusdrikking og det å se på tv mer enn fire timer daglig.

Tabell 4 viser estimatene fra en blokkvis hierarkisk ordinal logistisk regresjon med selvrapportert helse som avhengig variabel. I følge antagelsen om at helseatferd er en sentral mekanisme for ulikhet i helse skulle vi forvente at sammenhengen mellom SØS og selvrapportert helse ville forsvinne eller bli betydelig redusert når helseatferd ble inkludert i modellen. Kontrollert for alder og SØS var det en betydelig reduksjon i odds ratioen for dårligere helse etter at helseatferd ble inkludert i modellen, men sammenhengen var fremdeles statistisk signifikant. For gutter var reduksjonen relatert til helseatferd fra 1,70 til 1,42 , for jenter var reduksjonen fra 2,11 til 1,73.

Som en avsluttende analyse ble de enkelte helseatferdenes bidrag til å forklare sosioøkonomiske forskjeller i helse estimert $i$ en samlet stianalyse, der totale effekter av SØS på selvrapportert helse ble dekomponert til indirekte og direkte effekter. Tabell 5 viser resultatene fra en trimmet stimodell der kun statistisk signifikante mellomliggende variabler ble inkludert. Daglig tobakksrøyking, daglig fysisk aktivitet av en times varighet og daglig inntak av frukt og grønnsaker hadde statistisk signifikante mellomliggende sammenhenger med selvrapportert helse. Av en total standardisert sammenheng på 0,13 mellom SØS og selvrapportert helse var 0,11 mediert via de tre atferdstypene. For jenter var den totale sammenhengen mellom SØS og selvrapportert helse 0,16 , hvorav 0,10 var mediert via helseatferd. For både gutter og jenter var røyking den atferden som ga sterkest bidrag, etterfulgt av fysisk aktivitet.

\section{DISKUSJON}

Bidraget fra denne studien kan oppsummeres i tre punkter. For det første viser studien sosioøkonomiske forskjeller på tvers av atferdsområder, mens tidligere studier har fokusert på enkeltområder. For det andre viser studien at disse forskjellene kan bidra til å forklare en del av ulikheten i ungdoms selvrapporterte helse. Sist, men ikke minst, har vi vist at de sosioøkonomiske forskjellene $\mathrm{i}$ helse og helseatferd er relativt uavhengige av psykososiale forhold. Kontroll for psykososiale forhold hadde liten effekt på de sosioøkonomiske forskjellene i ungdoms helseatferd. Helseatferd forklarte sosioøkonomiske forskjeller i selvrapportert helse utover det psykososiale forhold gjorde.

Stianalysen gjorde det mulig å kvantifisere den enkelte atferds bidrag til å forklare ulikhet i helse. I forhold til tidligere studier er dette et viktig fortrinn, fordi disse har vært basert på separate regresjonsligninger med kontroll for helseatferd, snarere enn estimering av den indirekte effekten. Dekomponeringen av direkte og indirekte effekter viste at daglig fysisk aktivitet og 
Tabell 2. Prosentvis fordeling i helse og helseatferd etter familiens sosioøkonomiske status, separat for gutter og jenter.

\begin{tabular}{|c|c|c|c|c|c|c|}
\hline & \multicolumn{2}{|c|}{ Lav SØS } & \multicolumn{2}{|c|}{ Middels SØS } & \multicolumn{2}{|c|}{ Нøу SØS } \\
\hline & $\%$ & $95 \% \mathrm{KI}$ & $\%$ & $95 \% \mathrm{KI}$ & $\%$ & $95 \% \mathrm{KI}$ \\
\hline \multicolumn{7}{|c|}{ Ikke god helse } \\
\hline Gutt & 19 & $(16-23)$ & 16 & $(14-18)$ & 10 & $(8-13)$ \\
\hline Jente & 25 & $(21-29)$ & 21 & $(19-23)$ & 15 & $(12-18)$ \\
\hline \multicolumn{7}{|c|}{ Daglig tobakksrøyking } \\
\hline Gutt & 8 & $(5-10)$ & 5 & $(4-6)$ & 3 & $(2-5)$ \\
\hline Jente & 15 & $(12-18)$ & 5 & $(4-6)$ & 3 & $(2-5)$ \\
\hline \multicolumn{7}{|c|}{ Full fire ganger eller mer } \\
\hline Gutt & 17 & $(14-21)$ & 14 & $(12-16)$ & 16 & $(13-20)$ \\
\hline Jente & 16 & $(13-20)$ & 13 & $(11-15)$ & 15 & $(12-19)$ \\
\hline \multicolumn{7}{|c|}{ Fjernsyn fire timer eller mer } \\
\hline Gutt & 24 & $(21-28)$ & 17 & $(15-18)$ & 12 & $(10-15)$ \\
\hline Jente & 29 & $(24-33)$ & 19 & $(16-21)$ & 10 & $(7-13)$ \\
\hline \multicolumn{7}{|c|}{ Søtsaker daglig } \\
\hline Gutt & 13 & $(10-16)$ & 9 & $(8-11)$ & 6 & $(4-8)$ \\
\hline Jente & 16 & $(13-20)$ & 11 & $(9-13)$ & 8 & $(6-10)$ \\
\hline \multicolumn{7}{|c|}{ Sukkerholdig brus daglig } \\
\hline Gutt & 24 & $(20-28)$ & 17 & $(15-18)$ & 11 & $(8-13)$ \\
\hline Jente & 20 & $(16-24)$ & 11 & $(10-13)$ & 4 & $(3-6)$ \\
\hline \multicolumn{7}{|c|}{ Frukt daglig } \\
\hline Gutt & 27 & $(24-31)$ & 31 & $(29-34)$ & 38 & $(33-42)$ \\
\hline Jente & 35 & $(31-39)$ & 45 & $(42-47)$ & 55 & $(51-60)$ \\
\hline \multicolumn{7}{|c|}{ Grønnsaker daglig } \\
\hline Gutt & 18 & $(15-21)$ & 23 & $(21-25)$ & 33 & $(29-37)$ \\
\hline Jente & 25 & $(21-29)$ & 30 & $(28-33)$ & 43 & $(38-47)$ \\
\hline \multicolumn{7}{|c|}{ Fysisk aktiv minst en time daglig } \\
\hline Gutt & 13 & $(10-16)$ & 16 & $(14-18)$ & 20 & $(16-24)$ \\
\hline Jente & 8 & $(6-10)$ & 10 & $(9-12)$ & 14 & $(11-17)$ \\
\hline
\end{tabular}

Tabell 3. Sammenheng mellom sosioøkonomisk status (SØS) og helseatferd uttrykt som odds ratio (OR), med høy SØS som referansekategori, justert for alder, familiestruktur og psykososiale forhold.

\begin{tabular}{|c|c|c|c|c|c|}
\hline \multirow[b]{2}{*}{ Avhengig variabel } & \multicolumn{2}{|c|}{ Lav SØS } & \multicolumn{2}{|c|}{ Middels SØS } & \multirow[t]{2}{*}{ Нøy SØS } \\
\hline & OR & $95 \% \mathrm{KI}$ & OR & $95 \% \mathrm{KI}$ & \\
\hline \multicolumn{6}{|c|}{ Daglig tobakksrøyking } \\
\hline Gutt & 2,84 & $(1,64-4,93)$ & 1,71 & $(1,01-2,89)$ & 1,00 \\
\hline Jente & 4,25 & $(2,35-7,70)$ & 1,67 & $(0,95-2,92)$ & 1,00 \\
\hline \multicolumn{6}{|c|}{ Full 4 ganger eller mer } \\
\hline Gutt & 1,30 & $(0,90-1,88)$ & 0,95 & $(0,71-1,28)$ & 1,00 \\
\hline Jente & 0,99 & $(0,67-1,46)$ & 0,95 & $(0,68-1,31)$ & 1,00 \\
\hline \multicolumn{6}{|c|}{ Frukt sjeldnere enn daglig } \\
\hline Gutt & 1,83 & $(1,31-2,24)$ & 1,49 & $(1,22-1,49)$ & 1,00 \\
\hline Jente & 2,13 & $(1,67-2,70)$ & 1,64 & $(1,35-2,04)$ & 1,00 \\
\hline \multicolumn{6}{|c|}{ Grønnsaker sjeldnere enn daglig } \\
\hline Gutt & 2,33 & $(1,76-3,10)$ & 1,83 & $(1,49-2,25)$ & 1,00 \\
\hline Jente & 2,56 & $(1,96-3,23)$ & 1,89 & $(1,56-2,27)$ & 1,00 \\
\hline \multicolumn{6}{|l|}{ Søtsaker daglig } \\
\hline Gutt & 2,38 & $(1,58-3,34)$ & 0,93 & $(0,85-1,02)$ & 1,00 \\
\hline Jente & 2,26 & $(1,50-3,41)$ & 1,47 & $(1,06-2,04)$ & 1,00 \\
\hline \multicolumn{6}{|c|}{ Sukkerholdig brus daglig } \\
\hline Gutt & 2,78 & $(1,98-3,90)$ & 1,74 & $(1,30-2,32)$ & 1,00 \\
\hline Jente & 4,81 & $(3,14-7,36)$ & 2,66 & $(1,82-3,90)$ & 1,00 \\
\hline \multicolumn{6}{|c|}{ Fysisk aktiv mindre enn en time daglig } \\
\hline Gutt & 1,80 & $(1,27-2,56)$ & 1,41 & $(1,09-1,84)$ & 1,00 \\
\hline Jente & 1,75 & $(1,19-2,63)$ & 1,54 & $(1,15-2,04)$ & 1,00 \\
\hline \multicolumn{6}{|c|}{ Ser på fjernsyn minst 4 timer daglig } \\
\hline Gutt & 2,21 & $(1,60-3,05)$ & 1,46 & $(1,10-1,93)$ & 1,00 \\
\hline Jente & 3,26 & $(2,29-4,64)$ & 2,14 & $(1,55-2,95)$ & 1,00 \\
\hline
\end{tabular}


Tabell 4. Multivariat ordinal logistisk regresjon, med selvrapportert helse som avhengig variabel, for sammenhengen med SØS, etter kontroll for alder, familiestruktur, psykososiale forhold og helseatferd.

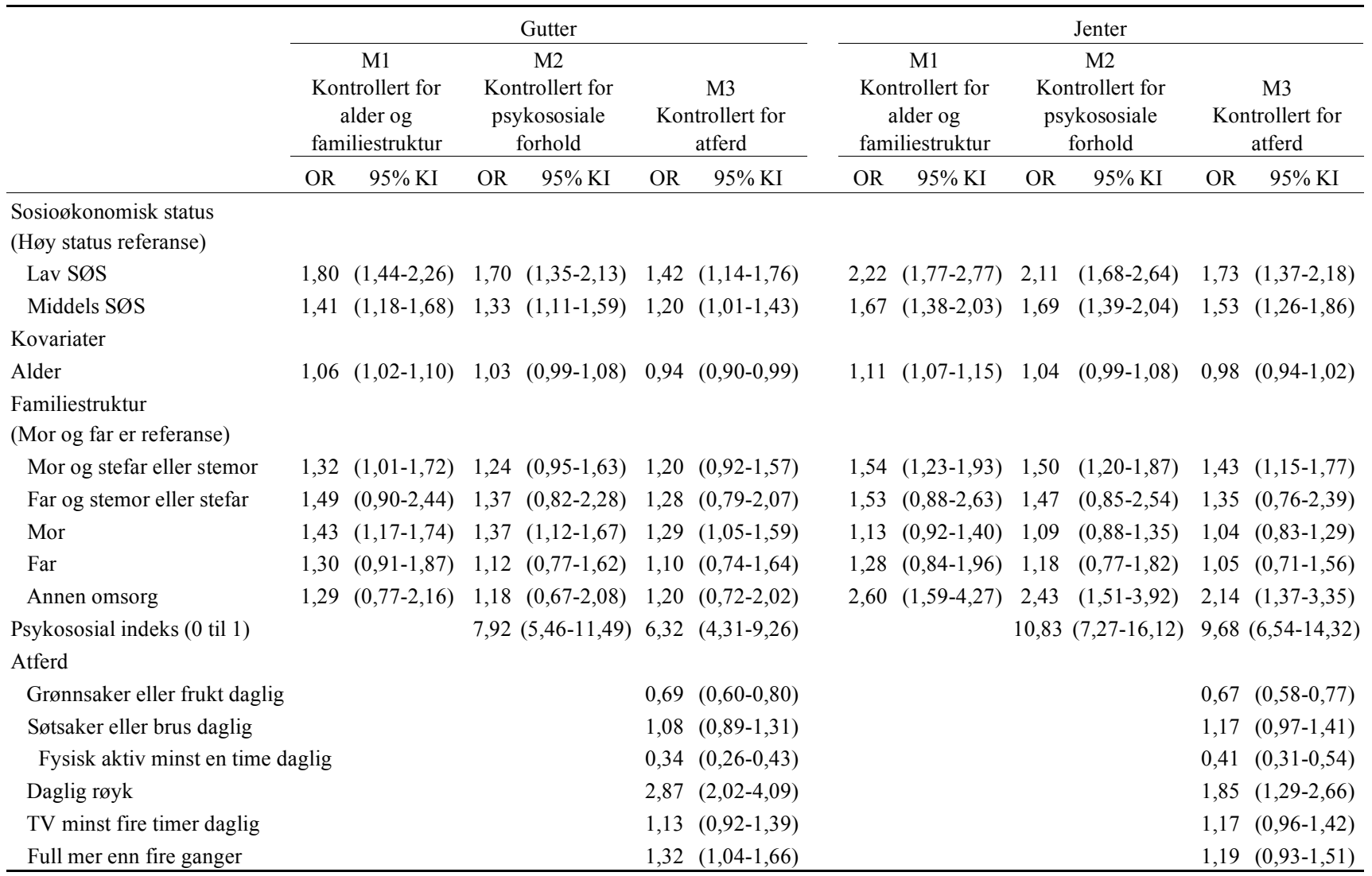

Tabell 5. Totale, indirekte og direkte sammenhenger mellom sosioøkonomisk status og selvrapportert helse fra stimodell med helseatferd og psykososiale forhold som mellomliggende variabler for sammenhengen mellom SØS og selvrapportert helse, justert for alder og familiestruktur.

\begin{tabular}{|c|c|c|c|c|c|c|c|c|}
\hline & \multicolumn{4}{|c|}{ Gutter } & \multicolumn{4}{|c|}{ Jenter } \\
\hline & $\begin{array}{l}\text { Estimat } \\
\text { (Z-skåre) }\end{array}$ & SE & $\mathrm{t}$ & $\begin{array}{c}\text { Standardisert } \\
\text { estimat (Z-skåre) }\end{array}$ & $\begin{array}{l}\text { Estimat } \\
\text { (Z-skåre) }\end{array}$ & SE & $\mathrm{t}$ & $\begin{array}{c}\text { Standardisert } \\
\text { estimat (Z-skåre) }\end{array}$ \\
\hline Total sammenheng & 0,45 & 0,08 & 5,97 & 0,13 & 0,55 & 0,08 & 7,38 & 0,16 \\
\hline Totale indirekte & 0,37 & 0,06 & 6,60 & 0,11 & 0,36 & 0,06 & 5,72 & 0,10 \\
\hline Via daglig fysisk aktivitet & 0,12 & 0,03 & 3,72 & 0,04 & 0,10 & 0,03 & 2,99 & 0,03 \\
\hline Via daglig røyking & 0,17 & 0,04 & 4,01 & 0,05 & 0,18 & 0,05 & 3,57 & 0,05 \\
\hline Via grønnsaker/frukt daglig & 0,04 & 0,02 & 2,24 & 0,01 & 0,04 & 0,02 & 1,96 & 0,01 \\
\hline Via psykososiale forhold & 0,04 & 0,01 & 3,17 & 0,01 & 0,05 & 0,02 & 3,00 & 0,01 \\
\hline Totale direkte & 0,08 & 0,08 & 1,08 & 0,02 & 0,19 & 0,09 & 2,26 & 0,05 \\
\hline
\end{tabular}

daglig tobakksrøyking var de viktigste mediatorene for sosioøkonomiske forskjeller i selvrapportert helse, mens kostholdsvaner og stillesittende aktivitet hadde en relativt liten effekt på selvrapportert helse. Det at sosioøkonomiske forskjeller i fysisk aktivitet og tobakksrøyking har sterkere forklaringskraft kan være særlig relevant i forhold til hjerte-karsykdommer, hvor fysisk aktivitet er en beskyttende faktor, og røyking er en risikofaktor.

SØS ble målt gjennom en kombinasjon av flere typer av indikatorer, inkludert mors og fars yrke, mate- rielle levekår og kulturell kapital. Denne indikatoren viste konsistente resultater på tvers av atferd. Tidligere forskning har i stor grad benyttet enkeltindikatorer på SØS. Det er grunn til å tro at slike enkeltindikatorer er mer følsomme for målefeil og tilfeldige fluktuasjoner. En mulig innvending kan være at en gjennom en slik datareduksjon taper informasjon om spesifikke sammenhenger. Dette informasjonstapet må imidlertid veies opp mot informasjonen en vinner gjennom økt konsistens i funn.

Et viktig aspekt ved studien er at vi har målt sam- 
menhengen mellom familiens sosioøkonomiske status og ungdoms helseatferd på et tidspunkt hvor helsevaner dannes. Disse atferdsmønstrene oppstår før ungdommen oppnår selvstendig sosioøkonomisk status, og seleksjon kan i stor grad utelukkes som forklaring på sammenhengen. I studier av voksenpopulasjoner finner en at sosioøkonomiske forskjeller $\mathrm{i}$ helseatferd bare kan forklare en liten del av ulikheten i hjerte-karsykdommer, til tross for at helseatferd er sentrale prediktorer for slike sykdommer $(18,19)$. En forklaring kan være at helseatferd etableres før voksenalderen og at den enkeltes SØS som voksen får en sekundær rolle i forhold til foreldrenes SØS. Enkelte studier tyder også på en motsatt kausalitet, hvor helseatferd som ung påvirker muligheten for utdanning og senere sosioøkonomisk status (20).

Sammenhengene mellom SØS og helseatferd tyder på at familiebakgrunn har betydning for valg av livsstil. Det er rimelig å tenke seg at sammenhengen representerer flere typer av mekanismer, både økonomiske og sosiale. Valg av sunne levevaner, som fysisk aktivitet og daglig inntak av frukt og grønnsaker, forutsetter at familien har god kjøpekraft. For eksempel vil det å være fysisk aktiv i organisert idrett kunne medføre en betydelig økonomisk startkostnad og vil deretter medføre vedvarende utgifter til utstyr, transport og deltagelse i turneringer og konkurranser. I Norge er grønnsaker og frukt dyrt sammenlignet med andre matvarer, og dette kan også bidra til sosial ulikhet i ungdoms forbruk av slike varer. Økonomiske forhold kan imidlertid ikke forklare hvorfor ungdom fra familier med lav SØS har klart høyere bruk av tobakksrøyking og høyere daglig inntak av søtsaker og sukkerholdig brus. I tillegg til økonomiske forhold vil også foreldres atferd, normer og verdier kunne utgjøre en sentral mekanisme. Studier har vist en betydelig sosial ulikhet i holdninger til atferd $(21,22)$ og helseatferd (19) blant voksne. Sammenhengen mellom familiens SØS og ungdoms tobakksrøyking kan skyldes at ungdom i familier med lav SØS har foreldre som røyker, slik at barna får positive inntrykk av tobakksrøyking, og videre at foreldrene ikke har effektive sanksjoner overfor ungdoms bruk av tobakk.

Sammenhengen mellom sosioøkonomisk status, helseatferd og helse var forholdsvis upåvirket av statistisk kontroll for psykososiale faktorer. Dette indikerer at sosial ulikhet mediert via atferd og sosial ulikhet mediert via psykososiale forhold representerer ulike typer av prosesser. I videre forskning vil det være sentralt å undersøke mekanismene for at ungdoms helseatferd viser samvariasjon med foreldres sosioøkonomiske status.

Studien har begrensinger. I studien ble selvrapportert helse brukt som kriterium for å vurdere den relative betydningen av helserelatert atferd. Et slikt subjektivt kriterium gir ikke sikker informasjon om sykelighet, og en kan derfor innvende at utfallsmålet har begrenset verdi som mål på helse. Vi vil likevel argumentere for at et slikt subjektivt kriterium kan være spesielt egnet for å vurdere mekanismer i sosial ulikhet $i$ helse hos ungdom, ettersom ungdom har liten variasjon sykelighet og dødelighet. Ungdom i skolepliktig alder har lav sykelighet og dødelighet, men selvrapportert dårlig helse har for voksne vist seg å være en prediktor for tidlig død (23) og kan derfor tjene som en markør for helsestatus.

Også atferdsmålene er basert på ungdommenes egne rapporteringer. Selvrapportert atferd er forbundet med målefeil, og dette gjelder kanskje særlig mål for fysisk aktivitet. Likevel viser ungdom tilfredsstillende reliabilitet i rapportering av helseatferd (24). Studien hadde et tverrsnittsdesign. Et slikt design kan kun gi et øyeblikksbilde av situasjonen og gir liten mulighet for å nå sikker kunnskap om hva som er årsaker og virkninger, men våre kausale antagelser er konsistente med data.

Vi har påvist sosial ulikhet i ungdoms helseatferd, men vi har ikke empirisk grunnlag for å anslå hva dette betyr for økt sykdomsrisiko i voksenalder. Likevel kan det være grunn til å forvente at kombinasjonen av vedvarende usunt kosthold, stillesittende atferd og lav grad av fysisk aktivitet medfører en okt risiko for overvekt, hjerte-karsykdommer og kreft. I et livsløpsperspektiv vil effektene av disse forskjellene først manifestere seg i økt sykelighet i et 30- til 40-års perspektiv. Skal en i fremtiden nå målsetningen om å redusere sosial ulikhet $\mathrm{i}$ helse, kan det derfor være nødvendig å fokusere på barn og unges helseatferd og hvordan slik atferd vedlikeholdes over tid.

\section{TAKKSIGELSER}

Forfatterne vil takke Folkehelseprogrammet i Norges Forskningsråd for finansiering av prosjektet.

\section{REFERANSER}

1. Marmot M, Shipley M, Brunner E, Hemingway H. Relative contribution of early life and adult socioeconomic factors to adult morbidity in the Whitehall II study. J Epidemiol Community Health 2001; 55 (5): 301-307.

2. West P. Health inequalities in the early years: Is there equalisation in youth? Soc Sci Med 1997; 44 (6): 833 858.

3. Goodman E. The role of socioeconomic status gradients in explaining differences in US adolescents' health. Am J Public Health 1999; 89 (10): 1522-1528. 
4. Starfield B, Riley AW, Witt WP, Robertson J. Social class gradients in health during adolescence. $J$ Epidemiol Community Health 2002; 56 (5): 354-361.

5. Halldorsson M, Kunst AE, Kohler L, Mackenbach JP. Socioeconomic inequalities in the health of children and adolescents - A comparative study of the five Nordic countries. Eur J Public Health 2000; 10 (4): 281288.

6. Torsheim T, Currie C, Boyce W, Kalnins I, Overpeck M, Haugland S. Material deprivation and self-rated health: a multilevel study of adolescents from 22 European and North American countries. Soc Sci Med 2004; 59 (1): 1-12.

7. Due P, Lynch J, Holstein B, Modvig J. Socioeconomic health inequalities among a nationally representative sample of Danish adolescents: the role of different types of social relations. $J$ Epidemiol Community Health 2003; 57 (9): 692-698.

8. Beiser M, Hou F, Hyman I, Tousignant M. Poverty, family process, and the mental health of immigrant children in Canada. Am J Public Health 2002; 92 (2): 220-227.

9. Vereecken CA, Inchley J, Subramanian SV, Hublet A, Maes L. The relative influence of individual and contextual socio-economic status on consumption of fruit and soft drinks among adolescents in Europe. Eur $J$ Public Health 2005; 15 (3): 224-232.

10. Geckova AM, van Dijk JP, Zezula I, Tuinstra J, Groothoff JW, Post D. Socio-economic differences in health among Slovak adolescents. Soz Praventivmed 2004; 49 (1): 26-35.

11. Tuinstra J, Groothoff JW, VandenHeuvel WJA, Post D. Socio-economic differences in health risk behavior in adolescence: Do they exist? Soc Sci Med 1998; 47 (1): 67-74.

12. Wills TA. Stress and coping in early adolescence - Relationships to substance use in urban school samples. Health Psychol 1986; 5 (6): 503-529.

13. Urban R, Kugler G, Olah A, Szilagyi Z. Smoking and education: Do psychosocial variables explain the relationship between education and smoking behavior? Nicotine Tob Res 2006; 8 (4): 565-573.

14. Bray JH, Adams GJ, Getz JG, Stovall T. Interactive effects of individuation, family factors, and stress on adolescent alcohol use. Am J Orthopsychiatry 2001; 71 (4): 436-449.

15. Currie C, Elton R, Todd J, Platt S. Indicators of socioeconomic status for adolescents: the WHO Health Behaviour in School-aged Children Survey. Health Educ Res 1997; 12 (3): 385-397.

16. Meulman JJ, Van der Kooij AJ, Heiser WJ. Principal component analysis with nonlinear optimal scaling transformations for ordinal and nominal data. In: Kaplan D, editor. The SAGE Handbook of Quantitative Methodology for the Social Sciences. Thousands Oaks: Sage, 2004: 49-70.

17. Schafer JL, Graham JW. Missing data: Our view of the state of the art. Psychol Methods 2002; 7 (2): 147-177.

18. Lantz PM, House JS, Lepkowski JM, Williams DR, Mero RP, Chen JM. Socioeconomic factors, health behaviors, and mortality - Results from a nationally representative prospective study of US adults. JAMA 1998; 279 (21): 1703-1708.

19. Winkleby MA, Jatulis DE, Frank E, Fortmann SP. Socioeconomic status and health: how education, income, and occupation contribute to risk factors for cardiovascular disease. Am J Public Health 1992; 82 (6): 816820.

20. Koivusilta L, Arja R, Andres V. Health behaviours and health in adolescence as predictors of educational level in adulthood: a follow-up study from Finland. Soc Sci Med 2003; 57 (4): 577-593.

21. Leganger A, Kraft P. Control constructs: Do they mediate the relation between educational attainment and health behaviour? J Health Psychol 2003; 8 (3): 361-372.

22. Iversen AC, Kraft P. Does socio-economic status and health consciousness influence how women respond to health related messages in media? Health Educ Res 2006; 21 (5): 601-610.

23. Idler EL, Benyamini Y. Self-rated health and mortality: a review of twenty-seven community studies. $J$ Health Soc Behaviour 1997; 38 (1): 21-37.

24. Torsheim T, Wold B, Samdal O, Haugland S. Test-retest reliability of survey indicators measuring adolescent health and health behaviour. University of Bergen: Research Centre for Health Promotion, 1997. 